\title{
THE INFLUENCE OF EXTERNAL FACTORS ON THE COMPETITIVENESS OF A COMPANY
}

\section{RAYNA DIMITROVA}

\begin{tabular}{|c|c|}
\hline & $\begin{array}{l}\text { South-West University, Blagoevgrad, Bulgaria } \\
\text { e-mail: rayna_dim@abv.bg }\end{array}$ \\
\hline $\begin{array}{l}\text { RECEIVED } \\
\text { ACCEPTED }\end{array}$ & $\begin{array}{l}18 \text { March } 2015 \\
6 \text { July } 2015\end{array}$ \\
\hline $\begin{array}{l}\text { JEL } \\
\text { CLASSIFICATION }\end{array}$ & M21 \\
\hline KEYWORDS & external factors, competitiveness, grades, indicators, furniture industry \\
\hline ABSTRACT & $\begin{array}{l}\text { External factors are influencing directly the competitiveness and the competitive potential of a company. } \\
\text { The analysis and the evaluation of the scope and sustainability of the influence of external factors is a condition } \\
\text { for the formulation of an adequate competitive strategy of a company. Within this context the goal of this } \\
\text { project is to conduct an empirical study of the influence of external factors for the competitiveness of furniture } \\
\text { producing companies, situated on the territory of the Blagoevgrad region. Conclusions are drawn on the basis } \\
\text { of the results of the empirical study. }\end{array}$ \\
\hline
\end{tabular}

\section{Introduction}

The study of the influence of external factors on the competitiveness allows the assessment of the state of the environment, the creation of objective forecasts for the changes in the conditions and factors, future opportunities and threats to this environment and their potential impact on the development of the enterprise. Therefore, the study of external competitiveness factors and their characteristics and effects is essential for making specific 
management decisions related to enhancing the competitiveness of the enterprise. The detection of the formation of their manifestation terms, their dynamics, impact force and the relationship between them is an important prerequisite for the formation of an adequate strategic and current behavior of the enterprise. The study of external factors of competitiveness is to: identify factors that have a direct impact on the respective business - sphere and determining the degree of importance of each factor, identify the key factors that the level of competitiveness of companies in a particular sector output trends and forecasting of climate factors in the external environment.

In this context, the objective of the study is to conduct an empirical study involving collection of information, processing of data on the basis of which an analysis and evaluation are drawn for the impact and sustainability of external factors for the competitiveness of enterprises in a particular sector of the economy, namely the sector "Furniture manufacturing", located in the Blagoevgrad region. To achieve the objective of the study an approach and methodology for characterizing the impact of external factors for the competitiveness of enterprises are applied based on data from surveys. In this sense, business surveys are an important information resource. Principally speaking, the information from business surveys provides estimates of the economic leaders of the past, present and short-term future state of the business environment. The theoretical basis of business study is Thomas' theorem, according to which if people define certain situations as real, they become real as a consequence (Мишев, 2010). As pointed out by Г. Мишев (2010a), despite the subjective nature of the responses, these studies provide reliable data because they relate to sides of the business activities that require the daily attention of the enterprise managers. In support of this is the opinion of Н. Николова (1998) that the use of specific "incomplete (partial) observations ", whose range includes surveys, stems from the objective need to timely meet the needs of data in order to be able to make quick and effective management decisions.

In order to gather the necessary primary empirical information for achieving the goals of the project a survey has been conducted for the period October-November 2013. The participants in the survey are forty companies engaged in the furniture production sector from all Blagoevgrad region municipalities (Note: The results from the survey are presented with those companies being numbered consecutively from 1 to 40). In the course of gathering information, representatives of the management of those companies were surveyed (owners, co-owners, directors, managers). The survey covers a period of three consecutive years 2011-2013. From the perspective of the most important characteristics of the profile of the enterprises according to their normative legal status, size etc., firstly it is required to point that the part of the enterprise, which is the subject of the survey in the separate municipalities corresponds to the part of the total registered companies within the furniture production sector of these municipalities. According to the legal form of registration of the businesses, the structure of the surveyed enterprises is the following: $77 \%$ from the companies are registered as limited liability companies single shareholder limited liability companies (44\%) and multiple shareholders limited liability companies (33\%). The percentage of sole proprietors, which are registered, is $11 \%$ of the surveyed companies and the share of jointstock companies is $10 \%$. The remaining $2 \%$ are various types of enterprises (cooperatives, general partnerships, limited partnerships and others). According to the date, it becomes clear that $56 \%$ of the surveyed companies are registered before 2004, 21\% from 2004 to 2007, 22\% of the registered enterprises from 2007 to 2012 and $1 \%$ are registered in 2013. There is an abrupt reduction of the number of newly registered enterprises during 2013, which is a reflection of the state of the economy of Bulgaria and particularly in the furniture production sector. Taking in account the number of employed personnel, the majority of the companies surveyed are micro and small enterprises (up to 50 workers employed), which constitute $88 \%$ of the surveyed companies, followed by medium 
sized enterprises (from 50 to 249 workers employed), which constitute 10\% and the share of large companies (employing more than 250 workers) is $2 \%$. The share of enterprises with foreign participation is relatively low (8\%). There are no significant forms of cooperation e.g. clusters, franchising and others, as only $5 \%$ of the companies declare such kind of participation.

In order to acquire the information, the method of direct surveying has been employed, where the survey participants are filling in the questionnaires themselves. The survey questionnaires have been proposed by М. Велев (2004) for the surveying of the competitiveness of the enterprise and its decisive factors, due to the fact that it corresponds to a high degree to the goals set for this current research. In order to create the databases and process the information, which was gathered, SPSS has been used, while for the graphic representation of the results of the survey Microsoft Excel has been employed.

\section{Problem definition}

The external factors of competitiveness of the enterprise are approached in a different way by a number of authors. According to the ability of the company to influence these factors B. ЦЦарев (2008) defines the external factors as factors, whose manifestation are dependent on the company in a minor degree. Р. Мадгерова (2012) separates the external factors in two groups:

- microenvironment factors, which indirectly influence the activity of the enterprise and include economic, political, demographic, technological, socio-cultural and environmental factors,

- microenvironment factors, which directly influence the activity of the enterprise and relate to the suppliers, clients and competitors.

Н. Казакова (2012) adds the factors of the microenvironment to the group of functional enterprises - leasing, consulting, engineering, factoring, franchising joint venture, etc. There are a number of approaches and methods for analysis of the macroenvironment of the company.

According to М. Велев (2004) the external factors of the competitiveness are macroeconomic, capital availability, labour market availability, resources for research and development, competition, cooperation and support from local competitive enterprises alongside distributors and intermediaries. С. Христов (2001) acknowledges that the marcoenvironment includes different political, economic, social, technological, financial, demographic, environmental and other factors, which affect immensely the present and future development of the organizations. Some authors (Morrison, 2006) use the category business environment, which is identified with all the factors surrounding it and influencing its organizational activity. R. Daft (1995) defines three major concepts connected to the business environment:

- organizational environment - includes all elements, which exist outside its boundaries and influence the organization as a whole or certain organizational activities,

- organizational field - chosen territory of the external environment, which the organization claims under the justification of acquired market positions via the services and products offered,

- operational field - includes sectors, which the organization interacts with directly and which influence the ability of the organization to achieve its goals.

The model of R. Daft for the environment of the organization includes the following elements:

- "Industry" - competitors,

- "Raw materials" - manufacturers and suppliers, 
- "Human resources" - labour market, employment, education,

- "Finances" - stock exchange, banks, savings, loans, private investors,

- "Market" - clients, potential users of products or services,

- "Technologies" - production technologies, science, research and development centers, new materials, automatization,

- "Economic conditions" - economic growth, inflation, unemployment, interest rate,

- "Government sector" - state, legislations, legal system, taxes, regulation, political system,

- "Socio-cultural sector" - values, beliefs, religion, ethics, "green" movements,

- "International sector" - competition from foreign enterprises, export, regulation and exchange.

D. Wilson (1992) indicates that the external business environment is defined from two sets of facts:

- objective facts, which characterize the objective reality could become a subject of measurement,

- subjective facts, which are defined on the basis of individual perceptions and interpretations.

The scientific literature defines different classifications of the forces of the external environment (Wetherly, Otter, 2008):

- PEST classification - classifying the forces of the external environment as economic, political, social and technological,

- SLEPT classification - defines the legal, social, economic, political and technological forces of the external environment,

- PESTEL classification - includes economic, social, legal, legislative, political, technological and ecological force,

- LEPEST classification - the forces of the external environment are economic, social, legislative, political, technological, ecological, competition,

- STEEPLE classification - defines the forces of the external environment as economic, social, legislative, political, technological, ecological, education,

- SPECTACLE classification - includes social, esthetic, political, economic, legal, cultural, technological forces as well as their clients and environment.

There is an interesting argument made by Г. Мишев (2010), who considers that the differences in qualifications of the forces of the business environment are within the range of its elements and presents a detailed systematization of the major characteristics of the elements of a business environment.

В. Златев (1999) defines the environment of the organization as external systems, which the enterprise exchanges human, material, financial and information resources with, thus influencing significantly the functioning of the organization. The author considers that the environment could be classified as general, when it is identified with the conditions, which influence all organizations and specific, when the environment interconnects with the existing infrastructure, the engaged organizations and the vendors, and creates a detailed characteristic of its general components. In support of this argument is also the statement made by A. Lahti (1986), which describes the common environment includes economic, legal, technological, social, political and other variables, which have a homogenizing effect.

И. Георгиев (2001) points out that the common environment includes "only these objects, processes, factors and conditions, which are connected to the behavior and functioning of the company" and creates a classification of the sectors and characteristics of the common environment. 
Exploring the analysis of the external environment of the enterprise, which he calls industrial analysis, У. Лашър (2001) defines a few stages for such a research:

- defining the economic and working profile of the activity,

- analysis of the competitive environment and the competitors,

- identifying the effects of the possible change of factors of the external environment,

- evaluation of the structure of the industry and its most significant competitors,

- identifying the key factors for success,

- general evaluation of the industrial environment.

Discussing the external factors of competitiveness of the enterprise, М. Велев (2004) classifies them in five groups, recommending concrete indicators in each group.

On the basis of the statements and classifications presented above, Table 1 is created, presenting a system of indicators for analysis and evaluation of the external factors of the competitiveness of the enterprise.

The questionnaire, which was used during the execution of the empirical research, consists of questions, which the respondents answer by grading the degree of their enterprise in all analysis indicator categories and evaluating the influence of the external competitiveness factors on the enterprise. In order to achieve this a scale with seven grades have been developed where the concrete meaning of every grade is the following:

- very low level/degree - grade 1 ,

- low level/degree - grade 2,

- satisfactory level/degree - grade 3,

- average level/degree - grade 4

- good level/degree - grade 5 ,

- high level/degree - grade 6,

- very high level/degree - grade 7.

The complex generalizing grade for the influence of the external factors of competitiveness on the enterprise is defined via the method of grading and can be calculated as a simple average with the following formula:

where:

$$
K_{j}=\frac{\sum_{k=1}^{s} B_{j k}}{k},
$$

$K_{j i}$ - being the grade of the influence of external factors of competitiveness of the j-company,

$j-$ index of the concrete enterprise, taking values in the interval $(1 \div m)$,

$k$ - index of the concrete indication, taking values in the interval $(1 \div s)$.

The influence of the external factors on the competitiveness of an enterprise are manifested in certain concrete conditions, such as a concrete market in a concrete period of time, have dynamic character and change over time. Therefore, it is necessary to analyze and evaluate the dynamics of the degree of influence of the external factors of competitiveness of a company in concrete timeframes or as М. Велев (2004) points out - to analyze the sustainability of such an influence. In order to meet the goals of this empirical research project the same methodology has been employed (Велев, 2004). 
Table 1. Measuring apparatus for analysis and evaluation of the impact of external factors on competitiveness

\begin{tabular}{|c|c|}
\hline Groups of factors & Indicators \\
\hline $\begin{array}{l}\text { 1. Political, legal } \\
\text { and macroeconomic } \\
\text { conditions }\end{array}$ & $\begin{array}{l}\text { 1.1. Political conditions - stability, predictability, tendencies for change and more } \\
\text { 1.2. General and sector-specific institutional structure } \\
\text { 1.3. Degree of bureaucracy } \\
\text { 1.4. Degree of corruption } \\
\text { 1.5. Macroeconomic situation } \\
\text { 1.6. Financial stability at the macroeconomic level } \\
\text { 1.7. Tax burden level } \\
\text { 1.8. The level and dynamics of per capita income } \\
\text { 1.9. Direct support access via different programs } \\
\text { 1.10. Strength and degree of influence of the professional, branch organizations } \\
\text { 1.11. Strength and degree of influence of the trade unions }\end{array}$ \\
\hline 2. Production factors & $\begin{array}{l}\text { 2.1. Availability of sufficient quantity and high quality material resources } \\
\text { 2.2. Weather } \\
\text { 2.3. Proximity to major external markets } \\
\text { 2.4. Presence in the labor market of the necessary human resources } \\
\text { 2.5. Availability of research potential } \\
\text { 2.6. Access to finance } \\
\text { 2.7. Level of infrastructure }\end{array}$ \\
\hline 3. Factors related to the search & $\begin{array}{l}\text { 3.1. Amount of domestic demand } \\
\text { 3.2. Growth rate of domestic demand } \\
\text { 3.3. Degree of segmentation of demand } \\
\text { 3.4. Degree of rigor of consumers to the enterprise's products } \\
\text { 3.5. The extent to which the requirements of local consumers are influenced by international market processes } \\
\text { 3.6. The extent to which local demand outstrips processes in the international markets } \\
\text { 3.7. Local search life cycle phase }\end{array}$ \\
\hline $\begin{array}{l}\text { 4. Factors related to market } \\
\text { competition }\end{array}$ & $\begin{array}{l}\text { 4.1. Competition intensity in the country } \\
\text { 4.2. Possibility of new competitors entering the market }\end{array}$ \\
\hline $\begin{array}{l}\text { 5. Factors associated } \\
\text { with the supporting } \\
\text { and related industries }\end{array}$ & $\begin{array}{l}\text { 5.1. Degree of competitiveness of the market for physical and financial resources } \\
\text { 5.2. Level of competitiveness of the suppliers for material and financial resources } \\
\text { 5.3. Intensity of competition between the suppliers of material and financial resources } \\
\text { 5.4. Degree of competitiveness in the sector, supporting the development of industry } \\
\text { 5.5. Level of competitiveness of the companies from the support industries } \\
\text { 5.6. Intensity of competition between firms from the support industries } \\
\text { 5.7. Level of competition in the broker sector } \\
\text { 5.8. Level of competitiveness between the broker enterprises } \\
\text { 5.9. Intensity of competition between the broker enterprises }\end{array}$ \\
\hline
\end{tabular}

Source: author's elaboration.

The methodology analyzes the sustainability of the influence of external factors on the competitiveness on an enterprise in two general directions:

1. Evaluating the static state of the degree of influence of the external factors of competitiveness. The following indicators are calculated:

- annual deviation of the grade of impact of external factors of competitiveness in comparison to the highest grade (due to the fact that for the goals of this research, the maximum grade of 7 has been employed, in the formulas to follow, such a grade has been used for calculations) via the dependence:

$$
\Delta K_{j i}=7-K_{j i},
$$


where:

$\Delta K_{j i}$ - being the annual deviation of the grade of impact of external factors of competitiveness on the $j$-enterprise for the year $i$ of the period discussed,

$K_{j i}$ - a grade for the influence of external factors of competitiveness on the $j$-enterprise for the year $i$ of the period discussed,

$j \quad$ - an index of the concrete enterprise, taking values in the interval $(1 \div m)$,

$i \quad$ - an index of the concrete year of the researched period, taking values in the interval $(1 \div n)$.

- annual deviation of the grade of impact of the external factors of competitiveness on the enterprise via the following dependency:

$$
\overline{\Delta K_{j}}=\frac{1}{n} \sum_{i=1}^{n} \Delta K_{j i}=\frac{1}{n} \sum_{i=1}^{n}\left(7-K_{j i}\right),
$$

$\overline{\Delta K_{j}}$ being the annual deviation of the grade of impact of the external factors of competitiveness on the enterprise of a company $j$ of the period, which is being researched.

The calculated annual deviation for every separate enterprise allows the researcher to compare the influence of external factors of competitiveness with other enterprises as well as with the average annual deviation of the whole group of competing enterprises.

The values of the calculated annual and average annual deviations could take values in the interval $(0 \div 6)$. The interpretation of these values is the following: the closer the annual and average annual deviations are to 0 , the higher the grades of the influence of external factors on the competitiveness of an enterprise and vice versa.

2. Evaluation of the dynamics of the influence of external factors of competitiveness on the enterprise. In order to achieve this, the absolute growth of the grades is being calculated in a chain frequency:

- the absolute growth of the grade of impact of the external factors of competitiveness of the enterprise via the dependency:

$$
\Delta K_{a j i, i-1}=K_{j i}-K_{j, i-1},
$$

$\Delta K_{a j i, i-1}$ being the absolute growth of the grade of impact of the external factors of competitiveness for enterprise $j$, concerning year $i$ as compared to the year $i-1$ of the discussed period.

- average absolute growth of the impact of external factors of competitiveness on the enterprise via the dependency:

$$
\overline{\Delta K_{a j}}=\frac{1}{n} \sum_{i=1}^{n}\left(K_{j i}-K_{j, i-1}\right),
$$

$\overline{\Delta K_{a j}}$ being the average absolute growth of the influence of the external factors of competitiveness on the enterprise $j$ for the researched period. 
The calculated values of the absolute growths of grades of the influence of the external factors of competitiveness on the enterprise, as well as their average annual figures could take values in the interval $(-6 \div 6)$. The interpretation of these values is the following: the more the absolute growths, respectively the average annual absolute growths, are closer to 6 , the more the dynamics of impact of the external factors of competitiveness on a given enterprise are favorable and vice versa. The absolute growths and the average annual absolute growths allow for a comparative analysis of the dynamics of influence of the external factors of competitiveness on the company.

\section{Survev resullts}

Table 2 presents the calculated, via the presented methodology, values of grades of impact of the external factors of competitiveness, their average annual deviation and absolute growth.

The data for 2011 indicates that the highest grade is 6.47 (enterprise no. 9), while the lowest is 2.59 (enterprise no. 33). The highest relative shares are of companies with grades from 3.00 to $3.99(47.5 \%)$, followed by those with grades from 4.00 to 4.99 (32.5\%). It is important to note that the enterprises with grades from 1 to 2.99 constitute $12.5 \%$, while the companies with grades from 1 to 4.99 are $92.5 \%$ of all enterprises.

During 2012, the relative share of companies with grades from 1.00 to $4.99(85.0 \%)$ is too high, however a positive change is observed with the increase of the relative share of enterprises with grades from 5.00 to 5.99 and the decrease of these grades from 1.00 to 2.99. A slight increase in the minimum grade is registered, being 2.47 (companies no.1 and no.31), while the highest is 6.44 (company no. 9).

The results according to the number and structure of the surveyed enterprises, their grades and the impact of the external factors of competitiveness for 2013 are very close to those for 2012. The relative share of enterprises with grades from 1.00 to 4.99 is $82.5 \%$ in total. Positive development is the increase in of companies with grades from 5.00 to 5.99 . The lowest grades are still kept by enterprises no. 1 and no. 31 , while the highest grade is still for enterprise no. $9-6.50$.

Table 2. Evaluation of the impact of the external factors of competitiveness on the enterprises for the period 2011-2013

\begin{tabular}{rccccc}
\hline \multirow{2}{*}{ Enterprise } & Impact of the external factors of competitiveness on the exterprise grade & Average annual deviation & Average annual growth \\
\cline { 2 - 5 } & 2011 & 2012 & 2013 & 5 & 6 \\
\hline 1 & 2 & 3 & 4 & 4.26 & 0.000 \\
\hline 1. & 2.74 & 2.74 & 2.74 & 3.06 & 0.000 \\
2. & 3.94 & 3.94 & 3.94 & 2.97 & 0.105 \\
3. & 3.94 & 4.00 & 4.15 & 2.20 & -0.085 \\
4. & 4.91 & 4.76 & 4.74 & 3.00 & 0.210 \\
5. & 3.79 & 4.00 & 4.21 & 2.38 & 0.000 \\
6. & 4.62 & 4.62 & 4.62 & 2.80 & -0.015 \\
7. & 4.21 & 4.21 & 4.18 & 3.38 & 0.000 \\
8. & 3.62 & 3.62 & 3.62 & 0.53 & 0.015 \\
9. & 6.47 & 6.44 & 6.50 & 2.56 & 0.000 \\
11. & 4.44 & 4.44 & 4.44 & 2.30 & 0.265 \\
12. & 4.44 & 4.68 & 4.97 & 2.57 & 0.175
\end{tabular}




\begin{tabular}{|c|c|c|c|c|c|}
\hline 1 & 2 & 3 & 4 & 5 & 6 \\
\hline 14. & 4.85 & 5.50 & 5.71 & 1.65 & 0.430 \\
\hline 15. & 5.41 & 5.44 & 5.44 & 1.57 & 0.015 \\
\hline 16. & 4.29 & 4.35 & 4.21 & 2.72 & -0.040 \\
\hline 17. & 4.94 & 5.21 & 5.53 & 1.77 & 0.295 \\
\hline 18. & 4.53 & 4.68 & 4.74 & 2.35 & 0.105 \\
\hline 19. & 4.97 & 5.15 & 5.38 & 1.83 & 0.205 \\
\hline 20. & 4.44 & 4.76 & 5.00 & 2.27 & 0.280 \\
\hline 21. & 3.50 & 3.38 & 3.38 & 3.58 & -0.060 \\
\hline 22. & 3.35 & 3.82 & 4.03 & 3.27 & 0.340 \\
\hline 23. & 3.06 & 3.59 & 3.47 & 3.63 & 0.205 \\
\hline 24. & 3.47 & 3.59 & 3.53 & 3.47 & 0.030 \\
\hline 25. & 3.91 & 4.06 & 3.85 & 3.06 & -0.030 \\
\hline 26. & 3.24 & 3.47 & 3.56 & 3.58 & 0.160 \\
\hline 27. & 3.41 & 3.53 & 3.59 & 3.49 & 0.090 \\
\hline 28. & 3.56 & 3.59 & 3.59 & 3.42 & 0.015 \\
\hline 29. & 3.74 & 3.82 & 3.85 & 3.20 & 0.055 \\
\hline 30. & 3.82 & 3.82 & 3.82 & 3.18 & 0.000 \\
\hline 31. & 2.74 & 2.74 & 2.74 & 4.26 & 0.000 \\
\hline 32. & 2.88 & 3.26 & 3.41 & 3.82 & 0.265 \\
\hline 33. & 2.59 & 2.91 & 3.32 & 4.06 & 0.365 \\
\hline 34. & 3.68 & 3.79 & 3.97 & 3.19 & 0.145 \\
\hline 35. & 2.91 & 3.26 & 3.35 & 3.83 & 0.220 \\
\hline 36. & 5.65 & 5.53 & 5.32 & 1.50 & -0.165 \\
\hline 37. & 3.97 & 3.94 & 4.21 & 2.96 & 0.120 \\
\hline 38. & 3.50 & 3.56 & 3.65 & 3.43 & 0.075 \\
\hline 39. & 3.09 & 3.47 & 3.65 & 3.60 & 0.280 \\
\hline 40. & 3.59 & 3.62 & 3.38 & 3.47 & -0.105 \\
\hline
\end{tabular}

Source: author's elaboration and calculations.

The distribution of the companies according to the values of their grades is presented in Table 3.

Table 3. Number and structure of enterprises according to the value of the grade of the impact of external factors of competitiveness for 2011-2013

\begin{tabular}{|c|c|c|c|c|c|c|}
\hline \multirow[b]{2}{*}{ Grades } & \multicolumn{2}{|c|}{2011} & \multicolumn{2}{|c|}{2012} & \multicolumn{2}{|c|}{2013} \\
\hline & $\begin{array}{c}\text { number } \\
\text { of companies }\end{array}$ & $\begin{array}{c}\text { relative share } \\
(\%)\end{array}$ & $\begin{array}{c}\text { number } \\
\text { of companies }\end{array}$ & $\begin{array}{c}\text { relative share } \\
(\%)\end{array}$ & $\begin{array}{c}\text { number } \\
\text { of companies }\end{array}$ & $\begin{array}{c}\text { relative share } \\
(\%)\end{array}$ \\
\hline From 1.00 to 2.99 & 5 & 12.5 & 3 & 7.5 & 2 & 5.0 \\
\hline From 3.00 to 3.99 & 19 & 47.5 & 18 & 45.0 & 18 & 45.0 \\
\hline From 4.00 to 4.99 & 13 & 32.5 & 13 & 32.5 & 13 & 32.5 \\
\hline From 5.00 to 5.99 & 2 & 5.0 & 5 & 12.5 & 6 & 15.0 \\
\hline From 6.00 to 7.00 & 1 & 2.5 & 1 & 2.5 & 1 & 2.5 \\
\hline Total & 40 & 100.0 & 40 & 100.0 & 40 & 100.0 \\
\hline
\end{tabular}

Source: author's elaboration and calculations. 
The calculated average annual deviations allow us to conduct a comparison of the degree of impact of the external factors of competitiveness for every single enterprise, as well as the average annual deviation for the whole sector of competing enterprises.

On the basis of Table 2 are calculated:

- average annual deviation of the grades of impact of the external factors of competitiveness for the whole sector of surveyed enterprises -2.913 ;

- a division of the enterprises has been made on the basis of the average annual deviation of the impact of external factors of competitiveness in Table 4.

Table 4. Number and structure of the enterprises according to the value of the average annual deviation of the external factors of competitiveness for 2011-2013

\begin{tabular}{lcc}
\hline \multicolumn{1}{c}{ Average Annual Deviation } & Number & Relative share (\%) \\
\hline From 0.00 to 0.99 & 1 & 2.5 \\
From 1.00 to 1.99 & 5 & 12.5 \\
From 2.00 to 2.99 & 12 & 30.0 \\
From 3.00 to 3.99 & 19 & 47.5 \\
From 4.00 to 4.99 & 3 & 7.5 \\
\hline Total & 40 & 100.0 \\
\hline
\end{tabular}

Source: author's elaboration and calculations.

The analysis of the results indicates that 24 companies (60\%) have an average annual deviation of the grade of impact of the external factors of competitiveness higher than 2.913 , therefore higher average annual deviations for the whole group; 16 enterprises (40.0\%) have an average annual deviation lower than 2.913 . The lowest deviation of 0.53 is for enterprise no. 9, while the highest is 4.26 for enterprises no. 1 and no. 31 . At the same time, Table 4 indicates that the biggest share of companies have an annual grade from 3.00 to 3.99 (47.5\%), followed by those with average annual deviations in the interval from 2.00 to $2.99(30.0 \%)$. These results lead to the justified conclusion that the overwhelming share of the enterprises surveyed posses levels of average annual deviations of the external factors of competitiveness, which can be evaluated as leaning towards satisfactory, average and good levels.

Table 5. Number and structure of the enterprises according to their average absolute growth of impact of the external factors of competitiveness for the period 2011-2013

\begin{tabular}{lcc}
\hline \multicolumn{1}{c}{ Average annual deviation } & Number & Relative share (\%) \\
\hline Less than 0.00 & 7 & 17.5 \\
From 0.00 to 0.20 & 23 & 57.5 \\
From 0.21 to 0.40 & 9 & 22.5 \\
From 0.41 to 0.60 & 1 & 2.5 \\
\hline Total & 40 & 100.0 \\
\hline
\end{tabular}

Source: own research and calculations. 
The analysis of the data in Table 2. indicates that the average annual growths of the impact of external factors of competitiveness are values, varying in the interval -0.165 (enterprise no. 36) to + (enterprise no. 14). The biggest share of enterprises $(57.5 \%)$ posses an average absolute growth from 0.00 to 0.20 followed by those, whose average absolute growth varies between 0.21 and $0.40(22.5 \%)$ - Table 5 . It is important to note that 7 companies have a negative average absolute growth of the impact of external factors of competitiveness for the period 2011 2013. Therefore, the dynamics of the impact of the external factors of competitiveness of the surveyed enterprises has a positive direction but has not fulfilled its potential yet.

\section{Conclusions}

The results of the empirical survey, which was conducted for the impact of external factors of competitiveness on the enterprise for the period of 2011-2013 allow us to formulate the following conclusions:

1. The grads, which the respondents give to the external grades of competitiveness are relatively low. This means that the majority of them consider that the factors of the external environment cause negative influence over the level of competitiveness of the companies.

2. The overwhelming majority of the surveyed enterprises possess degrees of the average annual deviation of the external factors of competitiveness, which could be evaluated as leaning towards satisfactory, average and good levels.

3. The influence of the external factors of competitiveness on the surveyed enterprises is varying insignificantly in a positive way within the frames of the period concerning the research.

\section{References}

Велев, М. (2004). Оценка и анализ на фирмената конкурентоспособност. София: Софттрейд [Velev, M. (2004). Ocenka i analiz na firmenata konkurentosposobnost. Sofia: Softtrejd].

Георгиев, И. (2001). Растежът на фирмата. София: УИ Стопанство [Georgiev, I. (2001). Rastezhyt na firmata. Sofia: UI Stopanstvo].

Златев, В. (1999). Мениджмънт без граници. София: УИ Стопанство [Zlatev, V. (1999). Menidzhmynt bez granici. Sofia: UI Stopanstvo].

Казакова, Н. (2012). Маркетинговый анализ. Москва: Инфрра-М [Kazakova, ‥ (2012). Marketingovыj analiz. Moskva: Infra-M].

Лашър, У. (2001). Стратегическо мислене за дребния бизнес и неговите подразделения. София: Лик [Lasher, U. (2001). Strategichesko mislene za drebniia biznes i negovite podrazdeleniia. Sofia: Lik].

Мадгерова, Р. (2012). Организация и управление на малкия бизнес. Благоевград: Лангов [Madgerova, R. (2012). Organizaciia i upravlenie na malkiia biznes. Blagoevgrad: Langov].

Мишев, Г. (2010). Статистическо характеризиране на бизнес средата. София: Авангард Прима [Mishev, G. (2010). Statistichesko harakterizirane na biznes sredata. Sofia: Avangard Prima].

Мишев, Г. (2010а). Статистическа оценка за бизнес средата на основата на данни от анкетни проучвания. Икономически алтернативи, 1: 10-19. [Mishev, G. (2010a). Statisticheska ocenka za biznes sredata na osnovata na danni ot anketni prouchvaniia. Ikonomicheski alternativi, 1: 10-19].

Николова, Н. (1998). Специфичните неизчерпателни статистически форми на наблюдение в съвременното изучаване на икономиката. Статистика, 3: 65-72. [Nikolova, N. (1998). Specifichnite neizcherpatelni statisticheski formi na nabliudenie v syvremennoto izuchavane na ikonomikata. Statistika, 3: 65-72].

Христов, С. (2001). Стратегически маркетинг в организацията. София: УИ Стопанство [Hristov, S. (2001). Strategicheski marketing v organizaciiata. Sofia: UI Stopanstvo].

Царев, В. (2008). Оценка конкурентоспособности предприятий (организаций). Теория и методология. Москва: ЮНИТИ -ДАНА [Carev, V. (2008). Ocenka konkurentosposobnosti predpriiatij (organizacij). Teoriia i metodologiia. Moskva: UNITI - DANA].

Daft, R. (1995). Organization Theory and Design. Eagan: West Publishing Company. 
Fleisher, C. \& Bensoussan, B. (2003). Strategic and Competitive Analysis. Methods and Techniques for Analyzing Business Competition. Upper Saddle River, New Jersey: Prentice Hall.

Lahti, A. (1986). Entrepreneurship, An Economic Perspective. Jilkaisuja D-83, Helsinki: Helsing Kauppakorkeakoulum.

Morrison, J. (2006). The International Business Environment. [e-book]. Second Edition. Basingstoke (England), New York: Palgrave Macmillan. Available at: www.palgrave.com/page/detail/the-international-business-environment-janet-morrison/?sf1=barcode\& st1 $=9780230209572$ (accessed 4.05.2013).

Wetherly, P. \& Otter, D. (2008). The Business Environment. Oxford: Oxford University Press.

Wilson, D. (1992). A Strategy of Change. London: Routledge.

Cite this article aS: Dimitrova, R. (2015). The influence of external factors on the competitiveness of a company. Szczecin University Scientific Journal, No. 883. Service Management, 16 (2): 37-48. 